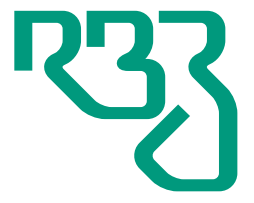

\section{Revista}

Brasileira de

Zootecnia

Brazilian Journal of Animal Science

ISSN 1806-9290

www.rbz.org.br

\title{
Eucalyptus oil to mitigate heat stress in broilers
}

\author{
Tiago Goulart Petrolli ${ }^{*}$ (iD), Maria Aparecida Sutille ${ }^{2}$ (iD), \\ Osmar José Petrolli² iD, Lenita Moura Stefani ${ }^{3}$ iD, \\ Anderson Tiecher Simionatto ${ }^{2}$ iD, Fernando de Castro Tavernari ${ }^{4}$ (iD), \\ Claiton André Zotti ${ }^{1}$ iD , Lilian Kolling Girardini ${ }^{1}$ (iD \\ ${ }^{1}$ Universidade do Oeste de Santa Catarina, Programa de Pós-graduação em Sanidade e \\ Produção Animal, Xanxerê, SC, Brasil. \\ ${ }^{2}$ Universidade do Oeste de Santa Catarina, Xanxerê, SC, Brasil. \\ ${ }^{3}$ Universidade do Estado de Santa Catarina, Departamento de Zootecnia, Chapecó, SC, Brasil. \\ ${ }^{4}$ Embrapa Suínos e Aves, Concórdia, SC, Brasil.
}

*Corresponding author: tiago.petrolli@unoesc.edu.br

Received: September 12, 2016

Accepted: December 19, 2018

How to cite: Petrolli, T. G.; Sutille, M. A.; Petrolli, O. J.; Stefani, L. M.; Simionatto, A. T.; Tavernari, F. C.; Zotti, C. A. and Girardini, L. K. 2019.

Eucalyptus oil to mitigate heat stress in broilers Revista Brasileira de Zootecnia 48:e20160306. https://doi.org/10.1590/rbz4820160306

Copyright: This is an open access article distributed under the terms of the Creative Commons Attribution License (http://creativecommons.org/licenses/by/4.0/) which permits unrestricted use, distribution, and reproduction in any medium, provided the original work is properly cited.

\begin{abstract}
The objective of this study was to evaluate performance, hematological parameters, leukocyte counts, and respiratory microbiota of broilers under heat stress receiving eucalyptus oil supplementation. Cobb broilers $(n=1200)$ were randomly distributed on the first day of life in a factorial arrangement with additional treatment $(2 \times 2+1)$ with two periods of oil administration via drinking water (daily, from 18 to 35 days of life) and two periods of oil administration via spray (daily, from 18 to 35 days of age) plus a control treatment, consisting of twelve replications, with 20 animals each. The birds were kept in a controlled environment with constant temperature at $32^{\circ} \mathrm{C}$ to induce heat stress by infrared heaters. Eucalyptus oil was supplied by drinking water $1 \mathrm{~L}$ of oil to $4000 \mathrm{~L}$ of water) or by spray applications with a pump (1 L of oil to $200 \mathrm{~L}$ of water). Bird weight was recorded at 42 days of age, along with remaining feed, to determine weight gain, feed intake, and feed conversion. In addition, one blood sample from each bird repetition was collected for hematological and leucocytic evaluation. To assess respiratory microbiota, a tracheal flushing was performed for bacteria counts. There was no difference in performance, hematological parameters, and leukocyte counts, except hematocrit, which was lower in birds that received eucalyptus oil after 18 days of age. No significant differences were observed in the respiratory microbiota comparing oil-treated and -untreated groups. Although it was not possible to verify statistical difference, the birds that received eucalyptus oil via spray plus spray from 18 days old showed lower bacterial counts and absence of isolation of Gram negatives, while the control group was the one with the highest number of Gram negatives. Therefore, eucalyptus oil can be used for heat-stressed broilers without impairing their development.
\end{abstract}

Keywords: additives, environment, essential oils, poultry

\section{Introduction}

Broiler under situations of heat stress may alter some metabolic functions in an attempt to maintain body temperature. However, such changes may lead to losses on performance (Belay and Teeter, 1993; Ribeiro et al., 2008; Oba, 2012) and immunodepression (Ribeiro et al., 2008).

High temperatures reduce feed intake, which can affect broiler performance, and low temperatures can improve weight gain, but with poor feed conversion. Environmental conditions must be handled with care, since they may affect animal metabolism, like body heat dissipation at high temperatures, with consequences to animal production, and incidence of metabolic diseases, such as pulmonary 
hypertension syndrome (ascites). Therefore, to obtain better performance while raising broilers, attention should be paid to the interaction between the animal and environment, so that the energy cost for physiological adjustments are kept to a minimum (Awaad et al., 2010).

Chickens under heat stress increase panting to maintain body temperature, which may overload their respiratory system, favoring microbial colonization and diseases. Thus, it is necessary to search for alternatives to minimize heat stress and its deleterious effects on birds and animal production.

Carli et al. (2008), Awaad et al. (2010), and Rehman et al. (2013) reported that eucalyptus oil is a promising alternative to improve thermal comfort to chickens, as well as their immune responses. This oil has positive effects in reducing thermal sensation in birds, promoting freshness in thermoregulatory sensors of the endocrine system, being an alternative to reduce the deleterious effects of heat on broilers (Awaad et al., 2010). Its essential oil has active molecules such as menthol and 1.8-cineol that can generate the feeling of freshness, stimulation of the immune system, inhibition of inflammatory responses, and antimicrobial effect (Rehman et al., 2013). Awaad et al. (2010) and Rehman et al. (2013) highlighted the antimicrobial and immunostimulatory effects of eucalyptus oil on the respiratory tract of birds, enhancing immune responses, and reducing the incidence of mucosal aggression in the respiratory tract of chickens (Cermelli et al., 2008). The immune system stimulation effect occurs due to the anti-inflammatory effect (Santos and Rao, 2000; Juergens et al., 2003; Greiner et al., 2013; Lima et al., 2013) and the stimulation of phagocytosis (Serafino et al., 2008; Yadav and Chandra, 2017) caused by 1.8-cineol in the organism.

The objective of the present study was to evaluate the effect of eucalyptus oil administered by drinking water or spray to heat-stressed broilers on animal performance, hematological parameters, leukocyte counts, and respiratory tract microbiota.

\section{Material and Methods}

This study was conducted on an experimental farm in Xanxerê, Santa Catarina, Southern Brazil $\left(26^{\circ} 50^{\prime} 10.6^{\prime \prime} \mathrm{S}\right.$ and $\left.52^{\circ} 24^{\prime} 27.9^{\prime \prime} \mathrm{W}\right)$. The experiment was approved by the Institutional Animal Ethics Committee, under case number 00632017. A total of 1200- one-day-old Cobb broilers, vaccinated in hatchery against Marek's, Gumboro, NewCastle, Poxvirus, and Avian Infectious Bronchitis diseases, were distributed in a completely randomized design, in a factorial arrangement with additional treatment $(2 \times 2+1)$, with two periods of oil administration via drinking water, two periods of oil administration via spray, and a control treatment (Table 1), consisting of twelve replicates with 20 animals each. The animals were raised as recommended for the lineage in an experimental farm, under controlled temperature of $32^{\circ} \mathrm{C}$ to induce thermal stress by infrared heaters. To increase health challenge, the birds were maintained on used litter, obtained from a commercial poultry farm with recent history of respiratory and digestive problems.

Eucalyptus oil was added to drinking water and offered in drinkers (one for each experimental unit) at a ratio of $1 \mathrm{~L}$ of oil to $4000 \mathrm{~L}$ of water, from 18 days of age (treatments 1 and 2) or from 35 days of age (treatments 3 and 4). The spray application (treatments 2 and 4) was performed daily with a back pump at the rate of $1 \mathrm{~L}$ of eucalyptus oil to $200 \mathrm{~L}$ of water (Table 1). Birds were housed in boxes of $2 \mathrm{~m}^{2}$ on wood shavings, and weighed at 42 days of life, along with food leftovers, to determine weight gain, feed intake, and feed conversion.

Table 1 - Experimental design

\begin{tabular}{lcc}
\hline Treatment & Water treatment (1:4000) & Spray treatment $(1: 200)^{2}$ \\
\hline T1 & After 18 days of life & - \\
T2 & After 18 days of life & 1 L of oil for 200 L of water \\
T3 & After 35 days of life & - \\
T4 & After 35 days of life & 1 L of oil for 200 L of water \\
T5 & Water only (control) & \\
\hline
\end{tabular}

$11 \mathrm{~L}$ of oil to $4000 \mathrm{~L}$ of water.

${ }^{2} 1 \mathrm{~L}$ of oil to $200 \mathrm{~L}$ of water. 
Blood samples ( $3 \mathrm{~mL}$ per broiler) were collected with EDTA from the brachial vein for hematological analyses (erythrocyte count, hematocrit, mean corpuscular volume (MCV), and mean corpuscular hemoglobin concentration (MCHC). Glass slides containing one drop of blood were examined under light microscope Olympus (BX51/BX52), with a final magnification of 1000x.

Evaluation of red blood cells, hemoglobin, and hematocrit was performed according to the technique described by Matos and Matos (1995). The mean corpuscular volume and the mean concentration of hemoglobin (MCH) were determined by Campbell (1988) method.

For leukocytic analysis, a sample of blood and Natt and Herrick's solution at a dilution of 1:200 were used, with subsequent counting of the cells in a Neubauer chamber, and the result multiplied by 120 . For the differential count, blood smears were prepared on glass slides, fixed with methanol for 5 min with subsequent staining with hematoxylin-eosin. The slides were washed with distilled water, air-dried, and smears observed under an optical microscope on an immersion objective. The leukocytic count was graded as granular (heterophils, eosinophils, and basophils) and non-granular cells (lymphocytes and monocytes) according to the methodology proposed by Gross and Siegel (1983), and the count was expressed as leukocytes per $\mu \mathrm{L}$.

For microbiological analyses, one 42-day-old bird per group was randomly selected for euthanasia and tracheal wash, by cervical dislocation, following the rules as recommended by CONCEA/MCTI (Brasil, 2013). First, trachea was dissected aseptically from the gular base region to the external base. Tracheal wash was performed using $10 \mathrm{~mL}$ of sterile saline solution $(0.85 \%)$, which was collected into a sterile tube, stored under refrigeration, and processed at the same day of sampling.

Aerobic mesophilic counts were performed as described by Silva et al. (2010), using PCA (Plate Count Agar, Oxoid). All samples were diluted to $10^{-2}$ in $0.85 \%$ sterile saline and incubated at $37^{\circ} \mathrm{C}$ for $48 \mathrm{~h}$. The number of colonies were counted, and the results were expressed as colony forming units per milliliter (cfu mL ${ }^{-1}$ ).

The samples were also inoculated onto 5\% Sheep Blood agar and MacConkey agar and incubated at $37^{\circ} \mathrm{C}$ for 24 to $48 \mathrm{~h}$ to identify the most prevalent microorganisms in accordance with the morphological and staining characteristics as described by Markey et al. (2013).

Performance data and hematological and microbiological analyzes were subjected to analysis of variance, and in case of significant differences, the average subjected to SNK test at 0.05 significance. Microbiological results were expressed in cfu. $^{-1}$, converted into a logarithmic scale, and the comparison between treatments performed from this data by nonparametric test Kruscal-Wallis test at $5 \%$ significance level. Analyses were performed using R Statistical software (R Development Core Team, 2009).

\section{Results}

No effects $(\mathrm{P}>0.05)$ were shown with the use of eucalyptus oil, via water or spray, in birds kept under heat stress, regarding live weight, gain weight, and feed intake in the period of 1-42 days (Table 2). Following the same trend of previous data, there was no statistical difference $(\mathrm{P}>0.05)$ among broilers of different treatments on feed conversion (Table 2).

Results from hematological tests (Table 3) showed no significant differences $(\mathrm{P}>0.05)$ in chickens receiving supplementation or subjected to spraying with eucalyptus oil compared with the control group regarding total erythrocytes, hemoglobin, MCV, and MCHC. These results indicate no metabolic changes in the body to influence the tissue oxygenation rate, very common in broilers kept under heat stress environments.

However, there was a significant difference $(\mathrm{P}<0.05)$ on the hematocrits, with lower percentages observed in birds treated after 18 days of age with eucalyptus oil, either via drinking water or via spray. In this case, there was bird adaptation to the oxygenation rate, enabling the maintenance of a lower hematocrit. Additionally, normal hematocrit for broilers lies in the range of 22 to $35 \%$. Eucalyptus essential oil did not affect $(\mathrm{P}>0.05)$ leucocyte counts (Table 4$)$, revealing no influence of eucalyptus oil on the immune response of treated broilers. 
The mesophilic average (Table 5), expressed in $\log 10 . \mathrm{g}^{-1}$, for treatment were: 2.34 (I from 18 days); 1.93 ( $+\mathrm{S}$ from 18 days), 2.34 (I after 35 days); 2.15 ( $+\mathrm{S}$ after 35 days), and 2.34 (control). It is not possible to see significant differences between the groups $(\mathrm{P}=0.835)$. The main microorganisms isolated in each group (Table 5) were very similar between the groups evaluated, showing the presence of Staphylococcus sp. in all groups.

Table 2 - Performance of broilers treated with eucalyptus oil via drinking water for a 42-day period

\begin{tabular}{lcccc}
\hline Water $(\mathrm{W})^{1}$ or spray $(\mathrm{S})^{2}$ & Body weight $(\mathrm{g})$ & Weight gain $(\mathrm{g})$ & Feed intake $(\mathrm{g})$ & Feed conversion $(\mathrm{g} / \mathrm{g})$ \\
\hline W after 18 days & 2404 & 2356 & 3930 & 1.67 \\
W after 18 days + S & 2402 & 2352 & 4238 & 1.80 \\
W after 35 days & 2354 & 2304 & 4056 & 1.76 \\
W after 35 days + S & 2220 & 2172 & 3870 & 1.82 \\
Control & 2402 & 2354 & 3841 & 1.63 \\
Interaction & $\mathrm{ns}$ & $\mathrm{ns}$ & $\mathrm{ns}$ & $\mathrm{ns}$ \\
P-value & 0.264 & 0.269 & 0.050 & 0.213 \\
CV (\%) & 8.10 & 8.27 & 7.03 & 10.92 \\
\hline
\end{tabular}

$\mathrm{CV}$ - coefficient of variation; ns - not significant.

${ }^{1}$ Ingestion via drinking water at the rate of $1 \mathrm{~L}$ of eucalyptus oil to $4000 \mathrm{~L}$ of water.

${ }^{2}$ Spray containing oil, applied on the birds at a ratio of $1 \mathrm{~L}$ of eucalyptus oil to $200 \mathrm{~L}$ of water.

Table 3 - Hematological analyses of broilers treated with eucalyptus oil via drinking water for a 42-day period

\begin{tabular}{lccccc}
\hline Water $(\mathrm{W})^{1}$ or spray $(\mathrm{S})^{2}$ & Total erythrocytes & $\begin{array}{c}\text { Hemoglobin } \\
(\mathrm{g} / \mathrm{dL})\end{array}$ & $\begin{array}{c}\text { Hematocrit } \\
(\%)\end{array}$ & $\begin{array}{c}\mathrm{MCV} \\
\left(\mu^{3}\right)\end{array}$ & $\begin{array}{c}\text { MCHC } \\
(\mathrm{g} / 100 \mathrm{dL})\end{array}$ \\
\hline W after 18 days & 2.62 & 19.69 & $32.37 \mathrm{~b}$ & 140 & 61.12 \\
W after 18 days + S & 2.62 & 19.63 & $32.00 \mathrm{~b}$ & 121 & 61.50 \\
W after 35 days & 2.55 & 20.77 & $34.50 \mathrm{ab}$ & 123 & 60.59 \\
W after 35 days +S & 2.55 & 20.92 & $35.37 \mathrm{a}$ & 134 & 59.15 \\
Control & 2.78 & 20.52 & $34.37 \mathrm{ab}$ & 129 & 59.74 \\
Interaction & $\mathrm{ns}$ & $\mathrm{ns}$ & $\mathrm{ns}$ & $\mathrm{ns}$ & $\mathrm{ns}$ \\
P-value & 0.795 & 0.549 & 0.012 & 0.175 & 0.953 \\
CV (\%) & 15.20 & 9.62 & 6.33 & 13.25 & 11.14 \\
\hline
\end{tabular}

MCV - mean corpuscular volume; MCHC - mean corpuscular hemoglobin concentration; CV - coefficient of variation; ns - not significant.

${ }^{1}$ Ingestion via drinking water at the rate of $1 \mathrm{~L}$ of eucalyptus oil to $4000 \mathrm{~L}$ of water.

${ }^{2}$ Spray containing oil, applied on the birds at a ratio of $1 \mathrm{~L}$ of eucalyptus oil to $200 \mathrm{~L}$ of water.

Means followed by different letters in the same column differ by SNK test at 0.05 significance level.

Table 4 - Leukocyte counts of broilers treated with eucalyptus oil via drinking water for a 42-day period

\begin{tabular}{|c|c|c|c|c|c|c|}
\hline Water $(\mathrm{W})^{1}$ or spray $(\mathrm{S})^{2}$ & $\begin{array}{c}\text { Total } \\
\text { leucocytes }\end{array}$ & Heterofils & Eosinofils & Basofiles & Monocytes & Linfocytes \\
\hline $\mathrm{W}$ after 18 days & 10950 & 4817 & 412 & 730 & 311 & 4679 \\
\hline $\mathrm{W}$ after 18 days $+\mathrm{S}$ & 6156 & 2905 & 342 & 406 & 327 & 2175 \\
\hline $\mathrm{W}$ after 35 days & 7937 & 2940 & 832 & 766 & 359 & 8082 \\
\hline Interaction & ns & ns & ns & ns & ns & ns \\
\hline P-value & 0.063 & 0.058 & 0.657 & 0.274 & 0.512 & 0.417 \\
\hline CV (\%) & 40.52 & 44.43 & 136.50 & 69.21 & 118.72 & 162.61 \\
\hline
\end{tabular}

$\mathrm{CV}$ - coefficient of variation; ns - not significant.

${ }^{1}$ Ingestion via drinking water at the rate of $1 \mathrm{~L}$ of eucalyptus oil to $4000 \mathrm{~L}$ of water.

${ }^{2}$ Spray containing oil, applied on the birds at a ratio of $1 \mathrm{~L}$ of eucalyptus oil to $200 \mathrm{~L}$ of water. 
Table 5 - Microbiological analyses of broilers treated with eucalyptus oil via drinking water for a 42-day period

\begin{tabular}{|c|c|c|}
\hline Water $(\mathrm{W})^{1}$ or spray $(\mathrm{S})^{2}$ & Count $(\log )^{\mathrm{ns}}$ & Isolated microorganism \\
\hline W after 18 days & 2.34 & Staphylococcus sp. and Escherichia coli \\
\hline $\mathrm{W}+\mathrm{S}$ after 18 days & 1.93 & Staphylococcus sp. \\
\hline W after 35 days & 2.34 & Staphylococcus sp., Aeromomas sp. and Proteus sp. \\
\hline $\mathrm{W}+\mathrm{S}$ after 35 days & 2.15 & Staphylococcus sp. and Aeromomas sp. \\
\hline Control & 2.34 & Staphylococcus sp. and Proteus sp. \\
\hline Interaction & ns & \\
\hline P-value & 8.835 & \\
\hline
\end{tabular}

ns - not significant.

${ }^{1}$ Ingestion via drinking water at the rate of $1 \mathrm{~L}$ of eucalyptus oil to $4000 \mathrm{~L}$ of water.

${ }^{2}$ Spray containing oil, applied on the birds at a ratio of $1 \mathrm{~L}$ of eucalyptus oil to $200 \mathrm{~L}$ of water.

\section{Discussion}

Broiler performance data (body weight, weight gain, and feed intake) presented no differences between the birds that received the different treatments. This result agrees with Rehman et al. (2013), who found no influence of the addition of eucalyptus oil on body weight of broilers from 1 to 42 days of age.

The absence of differences in feed conversion, when testing eucalyptus via drinking water found in this study, is consistent with reports by Rehmann et al. (2013), who found similar results between treated and untreated animals after checking weight gain and feed conversion weekly. However, the data diverge from Barbour et al. (2006) and Barbour et al. (2011), who reported improvement in feed conversion of broilers treated with eucalyptus oil via drinking water due to lower respiratory infections, frequency of aerosaculitis, and nasal and ocular discharge. The effectiveness of eucalyptus oil depends on the quality and quantity of their active molecules, the 1.8-cineol. Some authors (Faleiro et al., 2003; Dorman and Deans, 2000) described that essential oil composition and quantity varies depending on many factors linked to its origin, and environmental and genetic factors.

Damjanović-Vratnica et al. (2011) reported many benefits of eucalyptus oil, such as high antimicrobial effect (due to the 1.8-cineol effect), growth promoter or performance enhancer, disagreeing with our findings. Awaad et al. (2010), while evaluating the use of essential oils from eucalyptus and pepper in broilers, showed immunostimulatory effect of such additives in the body of the bird, which could improve animal performance.

The hematocrit of birds that received eucalyptus oil via drinking water and via drinking water + spray after 18 days of age was lower, which could be a great indicator of physiological adaptation to heat stress. As the thermoregulatory system of birds is not as developed, the main form of endogenous thermolysis of the bird is via panting (increased respiratory rate), which could adversely affect gas exchange rates, resulting in metabolic disorders due to a possible alkalosis. When the bird is subjected to a thermal environment which requires it to increase panting, the body increases the hematocrit in an attempt to compensate for the poor rate of gas exchange, which was not observed in birds treated with eucalyptus oil for a longer period. It can be stated that 1.8-cineol was effective in providing heat adaptation to the broilers.

Although differences were not found in performance, the lower hematocrit found in the experiment can be a good characteristic for longer-lived animals, like breeders and layers, which will have better heat adaptability. Because of the short-period of broiler raising, it was not possible to find changes in the performance of the birds.

The number of eosinophils, basophils, and heterophiles in the blood of broiler chickens kept under heat stress was not affected by the treatments with eucalyptus oil. The exposure to acute stress may result in a decreased proportion of monocytes and eosinophils in the blood (Bridi et al., 2012) due to the release of immunosuppressive hormones, such as epinephrine and cortisol. 
Barbour et al. (2011) tested the essential oil of eucalyptus in response to multiple respiratory infection agents in broilers, proving the efficacy of this substance on improving the fight against these agents, and suggested that the decrease of respiratory challenge can improve bird performance. These authors found an increase in final weight at the slaughterhouse when birds received eucalyptus oil via drinking water.

Although it was not possible to verify statistical difference, the birds that received eucalyptus oil via spray plus spray from 18 days old showed lower bacterial counts and the absence of isolation of Gram negatives, while the control group was the one with the highest number of Gram negatives. This data becomes relevant if we consider that infections of the respiratory tract are common in birds (Jordan and Pattisson, 1996) and carry serious economic damage to commercial poultry (Antão et al., 2008) by triggering significant levels of mortality and morbidity (Skyberg et al., 2003). Yadav and Chandra (2017) found enhanced phagocytic activity stimulated by 1.8-cineol, which can explain the data found in the present trial.

The antimicrobial effect of 1.8-cineol occurs due to its effect on bacterial cell membrane structure. This component has a lipophilic character, altering the membrane permeability and fluidity, affecting ion transport and the selective action of the membrane, compromising the enzyme activity and the homeostasis of bacterial cytoplasm.

In avian species, pathogenic Escherichia coli (APEC) are responsible for systemic diseases, leading to respiratory tract infection, which later evolves into a colisepticemia with colonization of internal organs such as heart, liver, and spleen (Moulin-Schouleur et al., 2007). The absence of difference found in eosinophils, basophils, and heterophiles levels in the blood of broilers indicates that the microbial profile isolated among birds could not alter the immune response of the broilers evaluated.

Damjanović-Vratnica et al. (2011) found great potential antimicrobial effect of eucalyptus oil, especially against Streptococcus pyogenes, Escherichia coli, Candida albicans, Staphylococcus aureus, Acinetobacter baumannii, and Klebsiella pneumoniae. The authors stated that the antimicrobial effect is due to the presence of monoterpenes and oxygenated monoterpenes, which is the main group of bactericidal molecules present in eucalyptus.

The quality of the air breathed increases the possibility of lesions in the respiratory tract, providing ideal conditions for the installation and replication of infectious agents. In this sense, it can be inferred that, although the application of eucalyptus oil via spray did not cause direct effect on animal development, this may have an antiseptic action capable of preventing respiratory infections.

\section{Conclusions}

Eucalyptus oil via drinking water or spray can be used in heat-stressed broilers, causing no detrimental effect on performance, hematological parameters, and leukocyte counts. Additionally, eucalyptus oil can potentially control the respiratory microbiota of these birds.

\section{Acknowledgments}

The authors thank the Konkreta Nutrition Technology (Chapecó, SC, Brazil), for making this research possible; and the Conselho Nacional de Desenvolvimento Científico e Tecnológico (CNPq), for the scholarship.

\section{References}

Antão, E. M.; Glodde, S.; Li, G.; Sharifi, R.; Homeier, T.; Laturnus, A. C.; Diehl, I.; Bethe, A.; Philipp, H. C.; Preisinger, R.; Wieler, L. H. and Ewers, C. 2008. The chicken as a natural model for extraintestinal infections caused by avian pathogenic Escherichia coli (APEC). Microbial Pathogenesis 45:361-369. https://doi.org/10.1016/j.micpath.2008.08.005

Awaad, M. H. H.; Abdel-Alim, G. A.; Sayed, K. S. S.; Kawkab, A.; Ahmed, A.; Nada, A. A.; Metwalli, A. S. Z. and Alkhalaf, A. N. 2010. Immunostimulant effects of essential oils of peppermint and eucalyptus in chickens. Pakistan Veterinarian Journal 30:61-66.

R. Bras. Zootec., 48:e20160306, 2019 
Barbour, E. K.; El-Hakim, R. G.; Kaadi, M. S.; Shaib, H. A.; Gerges, D. D. and Nehme, P. A. 2006. Evaluation of the histopathology of the respiratory system in essential oil-treated broilers following a challenge with Mycoplasma gallisepticum and/or H9N2 Influenza virus. International Journal of Applied Research and Veterinary Medicine 4:293-300.

Barbour, E. K.; Yaghi, R. H.; Jaber, L. S.; Shaib, H. A. and Harakeh, S. 2011. Safety and antiviral activity of essential oil against Avian Influenza and Newcastle Disease virus. International Journal of Applied Research and Veterinary Medicine 8:60-64.

Belay, T. and Teeter, R. G. 1993. Broiler water balance and thermobalance during thermoneutral and high ambient temperature exposure. Poultry Science 72:116-124. https://doi.org/10.3382/ps.0720116

Brasil. Ministério da Ciência, Tecnologia e Inovação. 2013. Diretrizes para a prática de eutanásia do CONCEA. MCTI Brasília.

Bridi, A. M.; Fonseca, A. M. N.; Silva, C. A.; Balarin, M. R. S.; Flaiban, K. K. M. C.; Costantino, C.; Tarsitano, M. A. and Cardoso, T. A. B. 2012. Indicadores de estresse e qualidade da carne em frangos abatidos pelo método "Halal". Semina: Ciências Agrárias 33:2451-2460.

Carli, K. T.; Onat, K. and Gunaydin, E. 2008. Application of Mentofin $®$ in broilers with clinical Infectious Bursal Disease to reduce Escherichia coli related problems after vaccination against Newcastle Disease. Turkey Journal of Veterinary Animal Science 32:73-78.

Campbell, T. W. 1988. Avian haematology and cytology. Iowa State University Press, Iowa.

Cermelli, C.; Fabio, A.; Fabio, G. and Quaglio, P. 2008. Effect of Eucalyptus essential oil on respiratory bacteria and viruses. Current Microbiology 56:89-92. https://doi.org/10.1007/s00284-007-9045-0

Damjanović-Vratnica, B.; Đakov, T.; Šuković, D. and Damjanović, J. 2011. Antimicrobial effect of essential oil isolated from Eucalyptus globulus Labill. from Montenegro. Czech Journal of Food Science 29:277-284. https://doi.org/10.17221/114/2009-CJFS

Dorman, H. J. D. and Deans, S. G. 2000. Antimicrobial agents from plants: antibacterial activity of plant volatile oils Journal of Applied Microbiology 88:308-316. https://doi.org/10.1046/j.1365-2672.2000.00969.x

Faleiro, M. L.; Miguel, M. G.; Ladeiro, F.; Venâncio, F.; Tavares, R.; Brito, J. C.; Figueiredo, A. C.; Barroso, J. G. and Pedro, L. G. 2003. Antimicrobial activity of essential oils isolated from Portuguese endemic species of Thymus. Letters in Applied Microbiology 36:35-40. https://doi.org/10.1046/j.1472-765X.2003.01259.x

Greiner, J. F. W. ; Müller, J.; Zeuner, M. T.; Hauser, S.; Seidel, T.; Klenke, C.; Grunwald, L. M.; Schomann, T.; Widera, D.; Sudhoff,

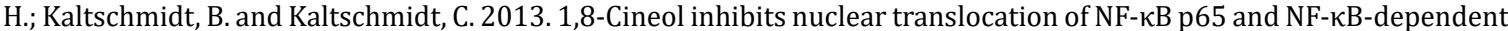
transcriptional activity. Biochimica et Biophysica Acta 1833:2866-2878. https://doi.org/10.1016/j.bbamcr.2013.07.001

Gross, W. B. and Siegel, H. S. 1983. Evaluation of the heterophil/lymphocyte ratio as a measure of stress in chickens. Avian Disease 27:972-979. https://doi.org/10.2307/1590198

Jordan, F. T. W. and Pattison, M. 1996. Poultry diseases. 4th ed. Saunders, London.

Juergens, U. R.; Dethlefsen, U.; Steinkamp, G.; Gillissen, A.; Repges, R. and Vetter, H. 2003. Anti-inflammatory activity of 1.8-cineol (eucalyptol) in bronchial asthma: a double-blind placebo-controlled trial. Respiratory Medicine 97:250-256. https://doi.org/10.1053/rmed.2003.1432

Lima, P. R.; Melo, T. S.; Carvalho, K. M. M. B.; Oliveira, I. B.; Arruda, B. R.; Brito, G. A. C.; Rao, V. S. and Santos, F. A. 2013. 1,8-cineole (eucalyptol) ameliorates cerulein-induced acute pancreatitis via modulation of cytokines, oxidative stress and NF-KB activity in mice. Life Sciences 92:1195-1201. https://doi.org/10.1016/j.lfs.2013.05.009

Markey, B. K.; Leonard, F. C.; Archambault, M.; Cullinane, A. and Maguire, D. 2013. Clinical veterinary microbiology. Elsevier, London.

Matos, M. S. and Matos, P. F. 1995. Hematologia clínica. In: Laboratório clínico médico veterinário. Matos, M. S. and Matos, P. F., eds. Atheneu, São Paulo.

Moulin-Schouleur, M.; Répérant, M.; Laurent, S.; Brée, A.; Mignon-Grasteau, S.; Germon, P.; Rasschaert, D. and Schouler C. 2007. Extraintestinal pathogenic Escherichia coli of avian and human origin: link between phylogenetic relationships and common virulence patterns. Journal Clinical Microbiology 45:3366-3376. https://doi.org/10.1128/JCM.00037-07

Oba, A.; Lopes, P. C. F.; Boiago, M. M.; Silva, A. M. S.; Montassier, H. J. and Souza, P. A. 2012. Características produtivas e imunológicas de frangos de corte submetidos a dietas suplementadas com cromo, criados sob diferentes condições de ambiente. Revista Brasileira de Zootecnia 41:1186-1192. https://doi.org/10.1590/S1516-35982012000500016

R Development Core Team. 2009. R: A language and environment for statistical computing. R Foundation for Statistical Computing, Vienna, Austria.

Rehman, S. R.; Muhammad, K.; Yaqub, T.; Khan, M.; Hanif, K. and Yasmeen, R. 2013. Antimicrobial activity of mentofin and its effect on antibody response of broilers to newcastle disease virus vaccine. The Journal of Animal \& Plant Sciences 23:1008-1011.

Ribeiro, A. M. L.; Vogt, L. K.; Canal, C. W.; Laganá, C. and Streck, A. F. 2008. Suplementação de vitaminas e minerais orgânicos e sua ação sobre a imunocompetência de frangos de corte submetidos a estresse por calor. Revista Brasileira de Zootecnia 37:636-644. https://doi.org/10.1590/S1516-35982008000400008

R. Bras. Zootec., 48:e20160306, 2019 

Santos, F. A. and Rao, V. S. 2000. Antiinflammatory and antinociceptive effects of 1,8-cineole
a terpenoid oxide present in many plant essential oils. Phytotherapy Research 14:240-244. https://doi.org/10.1002/1099-1573(200006)14:4\%3C240::AID-PTR573\%3E3.0.CO;2-X

Serafino, A.; Vallebona, P. S.; Andreola, F.; Zonfrillo, M.; Mercuri, L.; Federici, M.; Rasi, G.; Garaci, E. and Pierimarchi, P. 2008. Stimulatory effect of Eucalyptus essential oil on innate cell-mediated immune response. BMC immunology 9:17. https://doi.org/10.1186/1471-2172-9-17

Skyberg, J. A.; Horne, S. M.; Giddings, C. W.; Wooley, R. E.; Gibbs, P. S. and Nolan, L. K. 2003. Characterizing avian Escherichia coli isolates with multiplex polymerase chain reaction. Avian Diseases 47:1441-1447. https://doi.org/10.1637/7030

Silva, N.; Junqueira, V. C. C.; Silveira, N. F. A.; Taniwaki, M. H.; Santos, R. F. S. and Gomes, R. A. R. 2010. Manual de métodos de análise microbiológica de alimentos e água. Varela, São Paulo.

Yadav, N. and Chandra, H. 2017. Suppression of inflammatory and infection responses in lung macrophages by eucalyptus oil and its constituent 1,8-cineole: Role of pattern recognition receptors TREM-1 and NLRP3, the MAP kinase regulator MKP-1, and NFKB. Plos One 12:e0188232. https://doi.org/10.1371/journal.pone.0188232 